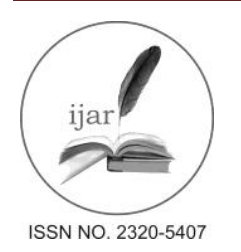

\author{
Journal homepage: http://www.journalijar.com

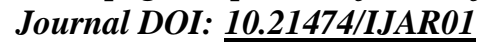

INTERNATIONAL JOURNAL

OF ADVANCED RESEARCH

RESEARCH ARTICLE

\title{
PHYTOCHEMICAL SCREENING AND ANTIOXIDANT ACTIVITY OF MAHONIA LESCHENAULTII WALL. AND PAVONIA ODORATA WILLD LEAVES.
}

\author{
Rajalakshmi $\mathbf{P}^{1}$, Vadivel $\mathbf{V}^{2}$, Subashini $\mathbf{G}^{3}$, and Pugalenthi $\mathbf{M}^{\mathbf{1}^{*}}$. \\ 1. Department of Botany, Government Arts College, Coimbatore-18. \\ 2. Department of CRISM, SASTRA University, Thanjavur, Tamil nadu, \\ 3. Department of Biotechnology, SNR \& Sons College Coimbatore.
}

\section{Manuscript Info}

Manuscript History:

Received: 17 March 2016

Final Accepted: 02 May 2016

Published Online: May 2016

Key words:

Antioxidant activity, Phytochemical screening, Mahonia leschenaulti,

Pavonia odorata, Medicinal plants.

*Corresponding Author

Rajalakshmi P.

\begin{abstract}
Medicinal plants being the effective sources of both traditional and modern medicines are genuinely useful for primary health care system. In the present study the leaves of potential medicinal plant $\mathrm{M}$. leschenaultii and P. odorata were subjected for phytochemical screening and evaluation of Antioxidant Activity. Phytochemical screening of petroleum ether and aqueous extracts clearly showed the presence of certain important secondary metabolites. Among the four extracts, the petroleum ether and aqueous extract was found to be more potent than other extract. The antioxidant activity of the plant extracts were determined by using phospho-molybdenum assay, Nitric oxide free radical scavenging assay and FRAP assay. The results of the present study clearly indicated that aqueous extract showed better nitric oxide free radical scavenging activity in $\mathrm{M}$. leschenaultii at concentration of $1000 \mathrm{mg} / \mathrm{ml}$ of extract, and followed by the other two assays in the same plant showed highest rate of antioxidant activity.
\end{abstract}

Copy Right, IJAR, 2016.. All rights reserved.

\section{Introduction:-}

A wide range of medicinal plants are used as extract for raw drugs and they possess varied medicinal properties. Some of these drugs are collected in smaller quantities by the local communities and folk healers for local use; many other raw drugs are collected in large quantities and traded in the market as the raw material by many herbal industries. (Uniyal et al.,2006).

Indian medicinal plants have made a good contribution to the development of ancient Indian Materia Medica. Ayurveda (the science of life), the Indian system of medicine is composed of two words, Ayu (Life) and Veda (Science). It utilizes plant, animal and mineral products for preserving and promoting health, and to cure diseases. It is a complete science of life and not merely a treatise on medicines or treatment of disease. All diseases, in Ayurveda, are supposed to be the result of imbalance among three members, ie., Vata (air), Pitta (bile), and cough (phlegm). The practice of use of herbal drugs in the treatment of various ailments dates to the days of the Rigveda, Bhrigutantra, Asvini Kumarar, Charak Samhita and Sushrutha Samhita and is well documented in Ayurvedic literature (Kokate, 1991). The Ayurveda system practiced in south India is termed as the 'Siddha' system of medicine. It relies on more on mineral drugs and has a unique way of processing herbs an minerals. It is supposed to have originated from Lord Shiva.

The majority of the bioactive phytochemical components in plants impart physiological activities and may offer a variety of health benefits such as antioxidant, antibacterial, anti-inflammatory or anticancer activity (Dorman and Deans, 2000). Medicinal plants have been used in traditional treatments for numerous human diseases for thousands of years, and they continue to be an important therapeutic aid for alleviating the ailments of humankind. The therapeutic benefits are generally traced to specific plant compounds; specifically due to the active constituents of the plants. 
Antioxidants are the compounds which terminate the attack of free radicals and thus reduce the risk of these disorders. Almost all organisms are protected up to some extent by free radical damage with the help of enzymes such as super-oxide dismutase, catalase and antioxidant compounds viz. ascorbic acid, tocopherol, phenolic acids, polyphenols, flavonoids and glutathione. Antioxidant supplements or dietary antioxidants protect against the damaging effects of free radicals. Presently, much attention has been focused on the use of natural antioxidants to protect the human body especially brain tissues from the oxidative damage caused by free radicals. In last two decades, several medicinal plants have shown such effectiveness through the traditional methods of psychoneuropharmacology (Kokate, 1991).

\section{Materials and methods:-} Collection of plant samples:-

Fresh plant Materials of Mahonia leschenaultii Wall. and Pavonia odorata Willd were collected from different agroclimatic regions of Avalanchi (Nilgiri district) and Kallaru (Coimbatore district) forest of Tamil Nadu, India, from natural strands. Fresh samples were washed under running tap water, air dried and then homogenized to fine powder and stored in airtight bottles.

\section{Extract preparation:- \\ Solvent extraction:-}

Fifty g of air- dried powder was taken in $200 \mathrm{ml}$ of petroleum ether/ Ethyl acetate/ Ethanol in a conical flask, plugged with cotton wool and they were shaken at room temperature for 2 days. After 2 days of incubation, the supernatant was collected and the solvent was evaporated to make the final volume one fourth of the original volume and stored at $4^{0} \mathrm{C}$ in airtight bottles.

\section{Aqueous extraction:-}

Fifty g of air-dried powder was taken in $200 \mathrm{ml}$ of water in a conical flask, plugged with cotton wool and they were shaken at room temperature for 2 days. After 2 days of incubation, the supernatant was collected and the solvent was evaporated to make the final volume one fourth of the original volume and stored at $4^{0} \mathrm{C}$ in airtight bottles.

\section{Screening of phytoconstituents:-}

Preliminary phytochemical analysis of various extracts:-

Qualitative phytochemical test were carried out in solvent and aqueous extracts of M. leschenaultii and P. odorata using standard procedure to identify the constituents by Trease and Evans (1989) and Harborne (1973) Methods.

\section{Antioxidant activity:-}

The antioxidant activity of crude extracts was determined by the following in-vitro methods.

\section{Phospo- molybdenum assay:-}

The total antioxidant capacity of the extracts were evaluated by the Phospho-molybdenum method described by Ali et al., (2008).The assay is based on the reduction of Mo (VI) to Mo (V) by the extract and subsequent formation of green phosphate /Mo complex at acidic pH.0.3 ml each extract (6\%) in triplicates were combined with $3 \mathrm{ml}$ of reagent solution $(0.6 \mathrm{M}$ sulfuric acid, $28 \mathrm{mM}$ sodium phosphate and $4 \mathrm{mM}$ Ammonium molybdate). The absorbance of the reaction mixture was measured at $695 \mathrm{~nm}$ using a spectrophotometer against blank after cooling to room

\section{Nitric oxide free radical scavenging assay:-}

Nitric oxide free radical scavenging assay was carried out as follows. Sodium nitropurusside $(10 \mathrm{Mm})$ in phosphate buffer ( $\mathrm{pH}$ 7.7) was incubated with $50 \mu \mathrm{g} / \mathrm{ml}$ of each extract (6\%) dissolved in their respective solvents in triplicate, and the tubes were incubated at room temperature for $150 \mathrm{~min}$. After incubation, $0.5 \mathrm{ml}$ of the rection mixture was diluted with $0.5 \mathrm{ml}$ of griess reagent (2\% ortho phosphoric acid, $1 \%$ sulphnilamide, $0.1 \%$ napthylethylenediamine). Ascorbic acid was used as the standard. The absorbance of the pink chromophore formed during diazotization of nitrite with sulphanilamide and subsequent coupling with $\mathrm{N}$-napthylethylendiamine was measured at $345 \mathrm{~nm}$ against the corresponding blank solution. Difference in obsorbance between the control and sample and expressed as percentage free radical scavenging of the nitric oxide by the extract (Hou et al., 1996).

$$
\text { Control OD - Sample OD }
$$

Control OD 


\section{Ferric Reducing Antioxidant Power assay (FRAP):-}

$3.6 \mathrm{ml}$ of FRAP solution $\left(0.3 \mathrm{M}\right.$ of Acetate buffer - pH 3.6; $10 \mathrm{Mm}$ of TPTZ in $40 \mathrm{mM}$ of HCL and $10 \mathrm{mM}^{\text {of } \mathrm{Fecl}_{3}}$ $\left.6 \mathrm{H}_{2} \mathrm{O}\right)$ is added to distilled water $(0.4 \mathrm{ml})$ and incubated at $37^{\circ} \mathrm{C}$ for $30 \mathrm{~min}$. Then this solution mixed with certain concentration of the plant extract $(30 \mathrm{ml})$ which was measured at $593 \mathrm{~nm}$. For construction of the calibration curve, five concentrations of $\mathrm{feSO}_{4}, 6 \mathrm{H} 2 \mathrm{O}(0.1,0.4,0.8,1,1.12,1.5 \mathrm{mM})$ were used and the absorbance values were measured as for sample solutions (Benzie et al., 1996).

\section{Results:-}

It is well recognized that free radicals are critically involved in various pathological conditions Such as cancer, cardiovascular disorders, arthritis, inflammation and liver disease under normal physiological conditions, low concentration of lipid peroxidation products are found in tissues and cells. In the presence of oxidative stress, more lipid peroxidation products are formed due to cell damage. Cellular antioxidant enzymes such as superoxides dismutase, glutathione peroxidise and catalase normally challenge oxidative stress.

\section{Phytochemical screening:-}

Solvent and aqueous extracts of the selected samples were subjected to qualitative organic analysis.

\section{Alkaloids:-}

Among both samples of the present study, only aqueous extract of P. odorata answered positively for Alkaloids (Table-I\&II).

\section{Tannins:-}

The ferric chloride test for the tannins were positively answered only by ethyl acetate extract of M. leschenaultii and P. odorata answered positively for tannin in ethanol extract (Table I\&II).

\section{Saponins:-}

Ethyl acetate extract of M. leschenaultii answered positively for saponins, where as P. odorata answered positively only in aqueous extract (Table I\&II).

\section{Flavonoid:-}

Among the plants of the present study, only petroleum ether extract of M. leschenaultii answered positively for flavonoids, and aqueous extract of P. odorata answered positively for flavonoids (Table I\&II).

\section{Steroids:-}

Both the plants of the present study, all the extract of M. leschenaultii and P. odorata answered positively for Steroids, and except aqueous extract of P. odorata (Table I\&II).

\section{Terpenoids:-}

Both the plants of the present study did not showed any positive result for terpenoids (Table I\&II).

\section{Antioxidant activity:- \\ Phospho-molybdenum assay:-}

The result of total antioxidant activity (TAC) by phosphor-molybdenum assay is shown in the (Table III). The extracts of a all the tested plant specimens possess total antioxidant activity ,but varying degrees, ranging from 3.067 to $7.68 \mathrm{mg} / \mathrm{ml}$. using the organic solvent extraction. A higher antioxidant activity was offered by ethanol extract of leaves of M. leschenaultii than P. odorata .

\section{Nitric oxide free radical scavenging assay:-}

The nitric oxide free radical scavenging assay of plant sample was given in (Table IV) which was found to be ranged from 3.069 to $54.155 \mathrm{mg} / \mathrm{ml}$. Among the two different plants, the M. Leschenaultii $(54.155 \mathrm{mg} / \mathrm{ml})$ have exhibited the highest rate of free radical scavenging activity, where as in P. odorata, it was found to be comparatively less.

\section{FRAP assay:-}

The total antioxidant activity of the studied plant sample is shown in the (Table V).The extracts showed considerable antioxidant activity ranging from $335.67 \mathrm{mg}$ of $\mathrm{FeSo}_{4} / \mathrm{g}$ of dry plant equalents in P. odorata (Ethanol338.69 mg/ml of $\mathrm{FeSo}_{4} / \mathrm{g}$ of dry plant equivalents in $\mathrm{M}$. leschenaultii aqueous extract. 


\section{Discussion:-}

Antioxidants protect human beings from harmful effects due to continuous synthesis of reactive oxygen species and related protein damage, DNA stand breaking and lipid peroxidation (srinivasan et al., 2007). Greater part of the world population, especially in third world countries, depend on the folk system of medicine for a number of diseases. Hundreds of plant genera are used medicinally, providing major sources of powerful and potent drugs (Ahmad et al., 1998 ). Many health problems, especially heart attack, cancer, AIDS, hepatitis, skin and gastrointestinal tract diseases atherosclerosis, arthritis, ischemia, and repercussion injury of many tissues, central nervous system injury, are proliferating rapidly in the whole world particularly in underdeveloped countries and their treatments by medicine (synthetic) are unaffordable by poor people or adversely affected.

Plant materials containing phenolic constituents are increasingly of interest for probing as they retard oxidative degradation of lipids and there by improve the quality and nutritional value of food. The importance of the antioxidant constituents of plant material in the maintenance of health and protection from coronary heart disease and cancer has been will recognized (Khalil et al., 2007). It has been recognized that flavonoids show antioxidant activity and their effects on human nutrition and health are considerable. The mechanisms of action of flavonoids are through scavenging or chelating process (Kessler et al., 2003). Phenolic compounds are a class of antioxidant agents which act as free radical terminators (Shahidi and Wanasundara, 1992).

\section{Phytochemical screening:-}

All plant parts synthesize some chemicals by themselves, to perform their physiological activities. In our present study, the investigated plants have exhibited different kinds of secondary metabolites. The medicinal value of these secondary metabolites is due to the presence of chemical substances that produce a definite physiological action on the human body. The most important of these substances include, alkaloids, glucosides, steroids, flavonoids, fatty oils, resins, mucilages, tannins, gums, phosphorus and calcium for cell growth, replacement, and body building (Kubmarawa et al., 2008)

Alkaloids derives from the "alkaline" and it was used to describe any nitrogen-containing base (Mueller-Harvey 1992). Alkaloids have many pharmacological activities including antihypertensive effects. ( many indole alkaloids), antiarrhythmic effect (quinidine, spareien), antimalarial activity (quinine), andanticancer actions (dimeric indoles, vincristine, vinblastine). Alkaloids with plants such as Nicotiana tobacum, Camelia sinensis and Atropa belladonna.

Saponins are a group of secondary metabolites found widely distributed in the plant kingdom. In medicine, it is used in hypercholesterolemia, hyperglycemia, antioxidant, anti-cancer, anti-inflammatory (Manach et al.,1996) central nervous system activities ( Argal and pathak,2006) and weight loss etc. it is also known to have antifungal properties. Saponins reduce the uptake of certain nutrients including glucose and cholesterol at the gut through intra-lumenal physicochemical interaction. Hence, it has been reported to have hypocholesterolemic effects (FAO/WHO/UNU 1991.) and thus, they may aid in lessening the metabolic burden that would have been placed on the liver. Plants with saponin Dioscorea villosa.

The flavonoids appear to have played a major role in successful medical treatments of ancient times, and their use has persisted up to now. Flavonoids have been reported to exert multiple biological property including antimicrobial, cytotoxicity, anti- Flavonoids have been stated to possess many useful properties, containing anti-inflammatory activity, enzyme inhibition, antimicrobial activity, oestrogenic activity, anti-allergic activity, antioxidant activity, vascular activity and cytotoxic antitumor activity (Tapas 2008 ). Flavonoids have been reported to exert multiple biological property including antimicrobial, cytotoxicity, anti- inflammatory as well as antitumor activities but the best-described property of almost every group of flavonoids is their capacity to act as powerful antioxidants which can protect the human body from free radicals and reactive oxygen species. The capacity of flavonoids to act as antioxidants. Plants with Flavonoids such Butea monosperma, Ocimum gratissimum, Bauhinia variegate are used for the treatment of various type of hepatic disorder In addition, terpenoids can have medicinal properties such as anti- carcinogenic (e.g. perilla alcohol), antimalarial (e.g. artemisinin), anti-ulcer, hepaticidal, antimicrobial or diuretic (e.g. glycyrrhizin) activity and the sesquiterpenoid antimalarial drug artimisinin and the diterpenoid anticancer drug taxol (Langenheim 1994, Dudareva 2004).

Plant steroids are known to be important for their cardiotonic activities, possession of insecticidal, anti-inflammatory (Akindele and Adeyemi, 2007), analgesic properties (Malairajan et al., 2006), central nervous system activites and 
antimicrobial properties. They are also used in nutrition, herbal medicine and cosmetics. Out of the six plants, studied steroids are present in Meliah azadiarch and Calotropis gigantea. (Argal and Pathak, 2006).

\section{Antioxidant activity:-}

\section{Phospho - molybdenum assay:-}

Phosphomolybdenum assay based on the reduction of $\mathrm{MO}(\mathrm{VI})-\mathrm{MO}(\mathrm{V})$ by the extract and formation of a MO (V) complex at acidic $\mathrm{p}^{\mathrm{H}}$. Increase in absorbance was observed by standard and extract. The total antioxidant activity of crude extracts of two plant specimens were ranged between from 3.067 to $7.68 \mathrm{mg} / \mathrm{ml}$. which is in agreement with that of the previous reports on Ficus racemosa $\mathrm{mg} / \mathrm{ml}$. ranging from (0.011 to 0.839) (Ravishankar and Vishnu priya.2012).

Nitric oxide free radical scavenging assay:-

Natural antioxidants that are present in herbs are responsible for inhibiting or preventing the deleterious consequences of oxidative stress. Herbs contain free radical scavengers like polyphenols, flavonoids and phenolic compounds. In the present study, we have evaluated the free radical scavenging activity of ethanol and aqueous extracts of M. leschenaultii and P. odorata leaves Among the four extracts and standard tested for the in vitro antioxidant activity using the Nitric oxide free radical scavenging method, the crude ethanolic extracts of P. odorata and M. leschenaultii leaves showed antioxidant activity of $4.79 \pm 0.002$ and $39.21 \pm 1.401 \%$ These value are found to be higher than that of the earlier report in Caesalpinia bonducella .(Rajalakshmi et al., 2015).

\section{FRAP assay:-}

Aqueous extract of $\mathrm{M}$. leschenaultii showed a considerable antioxidant activity ranging from 337.02 to 338.69 $\mathrm{mg} / \mathrm{ml} \mathrm{FeSO}{ }_{4} / \mathrm{g}$, which is compared higher than that of the earlier report on ethanol extracts of 0.684 to 0.411 of fresh leaves of Kalanchoe pinnata (Apak et al.,2004).

Table i:- Preliminary phytochemical screening of M. leschenaultia.

\begin{tabular}{|c|l|c|c|c|c|}
\hline \multirow{2}{*}{ S.No } & \multirow{2}{*}{ Phytoconstituents } & \multicolumn{4}{|c|}{ Plant extract } \\
\cline { 3 - 6 } & & $\begin{array}{c}\text { Petroleum } \\
\text { Ether }\end{array}$ & Ethyl acetate & Ethanol & Aqueous \\
\hline $\mathbf{1}$ & Alkaloids & -- & -- & -- & -- \\
\hline $\mathbf{2}$ & Tannins & -- & + & -- & -- \\
\hline $\mathbf{3}$ & Saponins & + & -- & + & + \\
\hline $\mathbf{4}$ & Flavonoids & + & -- & -- & -- \\
\hline $\mathbf{5}$ & Steroids & + & + & + & + \\
\hline
\end{tabular}

(+) Indicates Positive

(-- ) Indicates Negative

Table ii:- Preliminary phytochemical screening of P. odorata.

\begin{tabular}{|c|c|c|c|c|c|}
\hline \multirow{2}{*}{ S.No } & \multirow{2}{*}{ Phytoconstituents } & \multicolumn{4}{|c|}{ Plant extract } \\
\cline { 3 - 6 } & & $\begin{array}{c}\text { Petroleum } \\
\text { Ether }\end{array}$ & Ethyl acetate & Ethanol & Aqueous \\
\hline $\mathbf{1}$ & Alkaloids & -- & -- & -- & + \\
\hline $\mathbf{2}$ & Tannins & -- & -- & - & - \\
\hline $\mathbf{3}$ & Saponins & -- & -- & -- & + \\
\hline $\mathbf{4}$ & Flavonoids & -- & -- & + & + \\
\hline $\mathbf{5}$ & Steroids & + & + & -- & - \\
\hline $\mathbf{6}$ & Terpenoids & -- & -- & - \\
\hline
\end{tabular}

(+) Indicates Positive

(-- ) Indicates Negative 
Table iii:- Phospho-molybdenum assay in ethanol and aqueous extract of M. leschenaultii and P. odorata.

\begin{tabular}{|c|c|c|}
\hline \multirow{2}{*}{ Plant Species } & \multicolumn{2}{|c|}{$\begin{array}{c}\text { Total antioxidant activity } \\
\text { (mg Ascorbic acid equivalent / ml sample) }\end{array}$} \\
\cline { 2 - 3 } & \multicolumn{2}{|c|}{ Plant extract } \\
\cline { 2 - 3 } & Ethanol & Aqueous \\
\hline M. leschenaultii & $\mathbf{7 . 6 8} \pm \mathbf{0 . 2 7 4}$ & $3.85 \pm 0.597$ \\
\hline P. odorata & $4.79 \pm 0.022$ & $3.067 \pm 0.002$ \\
\hline
\end{tabular}

*Data are mean of three replicates, \pm standard error.

Table-iv Nitric oxide free radical scavenging assay in ethanol and aqueous extracts of M. leschenaultii and P. odorata

\begin{tabular}{|c|l|c|}
\hline \multirow{2}{*}{ Plant Species } & \multicolumn{2}{|c|}{ Radical scavenging activity (\%) } \\
\cline { 2 - 3 } & \multicolumn{2}{|c|}{ Plant extract } \\
\cline { 2 - 3 } & \multicolumn{1}{|c|}{ Ethanol } & Aqueous \\
\hline M. leschenaultii & $39.209 \pm 1.401$ & $\mathbf{5 4 . 1 5 5} \pm \mathbf{0 . 5 1 5}$ \\
\hline P. odorata & $4.785 \pm 0.022$ & $3.069 \pm 0.002$ \\
\hline
\end{tabular}

*Data are mean of three replicates, \pm standard error

Table v : FRAP assay in ethanol and aqueous extract of M. leschenaultii and P. odorata*

\begin{tabular}{|c|c|c|}
\hline \multirow[t]{3}{*}{ Plant Species } & \multicolumn{2}{|c|}{$\begin{array}{l}\text { Total antioxidant activity (mg } \mathrm{FeSO}_{4} \text { equivalent / } \\
\text { g sample) }\end{array}$} \\
\hline & \multicolumn{2}{|c|}{ Plant extract } \\
\hline & Ethanol & Aqueous \\
\hline M. leschenaultii & $337.02 \pm 0.287$ & $338.69 \pm 0.846$ \\
\hline P. odorata & $335.67 \pm 2.080$ & $336.74 \pm 0.771$ \\
\hline
\end{tabular}

*Data are mean of three replicates, \pm standard error

\section{Conclusion:-}

The potential medicinal plants may be recommended for the isolation and structural elucidation of important active principles, after conducting the suitable advanced studies for the effective utilization of this plants.

\section{Reference:-}

1. Ahmad I, Mehmood Z, Mohammad F. (1998) Screening of some Indian medicinal plants for their antimicrobial properties. J Ethnopharmacol; 62(2): 183-93.

2. Akindele, A.J. and Adenyemi, O.O.2007. Anti-inflammatory activity of the aqueous leaf extracts of Byrsocarpuscoccineus. Fitoterapia78: 25-28.

3. Ali Akbar Hossain ,SelimHossain . 2015. American Journal of Plant Science.(6):633-639.

4. Argal A. and Pathak A.K. 2006.CN Sactivity of Calotropisgigantearoots.J. Ethnopharmacol. 106: $142-145$.

5. Apak R, GuçluK, Ozyurek M, Karademir SE. (2004) Novel total antioxidant capacity index for dietary polyphenols and vitamins $\mathrm{C}$ and $\mathrm{E}$, using their cupric ion reducing capability in the presence of neocuproine: CUPRAC method. J Agric Food Chem; 52:7970-7981.

6. Benzie, I.F.; Strain, J.J. (1996). The ferric reducing ability of plasma (FRAP) as a measure of "antioxidant power": The FRAP assay. Anal.Biochem.,239: 70-76.

7. Dorman ,HJ and Deans, SG(2000). Antimicrobial agents from plants: antibscterial activity of plat volatile oils .J.Applmicrobial.88:308-316

8. Dudareva N, Pichersky E, Gershenzon J. Biochemistry of plant volatiles. Plant Physiology, 2004; 135: 18931902.

9. Dursum,E.,S. and Akcicek, E. (2004).Herbes as Food souece in Turkey. Asia pacific Cancer prev.5: $334-339$.

10. FAO /WHO /UNU. "Energy and Protein Requirements: Re- port of a Joint FAO/WHO/UNU Expert Consultation". WHO Technical Report Series. 1991.p.724.

11. Harborne,J B. (1973). Phytochemical Methods, A Guide to modern Techniques of Plant Analysis. Chapman and Hall, London. 33-41. 
12. Hou, D., K. Larsen \& S. S. Larsen, 1996.Caesalpiniaceae.Flora Malesiana, Series 1, 12(2): 409-730.

13. Kessler, R.C., Barker, P.R., Colpe, L.J., Epstein, J.F., Gfroerer, J. C., Hiripi, E., Howes, M.S Normand, S- L. T. and Manderscheid, R.W. 2003. Screening for serious mental illness in the general population archives of general psychiatry. $60(2)$ : 68-74

14. Khalil, MY., Moustafa, AA. And Naguib, N. 2007. Growth, phenolic compounds and antioxidant activity of some medicinal plants grown under organic farming condition. World J. Agri.Sci. 3(4): 451-457

15. Kokate, C,K. 1991.Practical Pharmacognocy, (Ed.III). VallabhPrakashan, Delhi. 107 and 115-125.

16. Kubmarawa, D., Khan, M.E. Punah, A.M. \& Hassan. 2008. Phytochemical screening and antibacterial activity of extracts from Parkiaclapper tonianakeay against human pathogenic bacteria. J. Med. Pl. Res. 2 (12) : $352-$ 355.

17. Langenheim JH. (1994) Higher plant terpenoids: A phytocentric overview of their ecological roles. Journal of Chemical Ecology; 20: 1223- 1280.

18. Malairajan, P., Geetha, G., narasinhan, S. \&Jessi Kala Veni, K.2006.Analgesic activity of someIndian medicinal plants. J. Ethnopharmacol.19: 425-428.

19. Manach, C., regerat, F. \&Texier, O. 1996.Bioavaillability, metabolism and physiological impact of4-oxoflavonoids. Nutr. Res. 16: 517-544.

20. Mueller-harvey I, Mcallan AB. (1992) Tannins: Their biochemistry and nutritional properties. Advances in plant cell biochemistry and biotechnology, Vol. 1 Morrison IM ed. JAI Press Ltd, London (UK); 151-217.

21. Rajalakshmi P, Vadivel V, Subhashini G, Pugalenthi M., 2015. Ptytochemical Screening and in vitro Antioxidant activity of Caesalpinia bonducella. Indian Journal of Appiled Research.5 (11).

22. Ravishankar.k and P.S Vishnu priya. (2012) Invitro antioxidant Activity of ethanolic seed extracts of Macrotyloma uniflora and Cucumis melofor therapeutic potential. International Journal of research in Pharmacy and Chemistry 2(2), 2231-2781.

23. Shahidi, F.and Wanasunndara, PKJPD., 1992. Phenolic antioxidants.Crit. Rev. Food Sci. Nut.32: 67-103

24. Srinivasan R, Chandrasekar MJ, Nanjan MJ, Suresh B. (2007) Antioxidant activity of Caesalpinia digyna root. J Ethnopharmacol; 113(2): 284-91.

25. Tapas AR, Sakarkar DM, Kakde RB. (2008) Flavonoids as Nutraceuticals: A Review.Tropical Journal of Pharmaceutical Research; 7: 1089-1099.

26. Uniyal S.K , K. N. Singh, P. Jamwal and B. Lal , (2006)Traditional use of medicinal plants among the tribal communities of chotta bhangal, western Himalayan J. Ethnobiol. Ethnomed, 2: 1- 4. 